\title{
MARKET ORIENTATION: THE CONCEPT AND ITS DEVELOPMENT
}

\section{Nandakumar Mekoth*}

\section{Introduction}

The concept of market orientation has been one of the most discussed and researched topics in the last decade. This paper attempts to bring out the meaning, need and features of market orientation and the steps involved in its implementation. The paper identifies the relationship of various related concepts with the concept of market orientation. The paper also traces back the development of the field of market orientation through literature survey and identifies the distinct stages in the process of development.

\section{Meaning and Definitions}

Market orientation is concerned with the processes and activities associated with creating and satisfying customers by continually assessing their needs and wants, and doing so in a way that there is a demonstrable and measurable impact on the business performance (Uncles, 2000). The central theme of this definition involves three concepts. First of all, market orientation is considered as a continuous "process". Second, it involves satisfying customer "needs". And third, it leads to

* Reader, Department of Management Studies, Goa University, Goa 
better business performance. In this sense customer orientation may be considered as properly aligned with the organizational goal of business performance.

Kohli and Jaworski (1990) compared the existing literature and field perspectives and came out with a definition which is more indebled to the field perspective. According to them market orientation entails (1) one or more departments engaging in activities geared toward developing an understanding of customers' current and future needs and the factors affecting them, (2) sharing of this understanding across departments, and (3) the various departments engaging in activities designed to meet select customer needs. The advantage of this definition was the ease of operationalisation for further empirical research. This definition views market orientation as an activity and treats business performance and customer satisfaction as outcomes of market orientation implicitly by omitting those terms from the definition.

Deng and Dart (1994) define market orientation as the generation of appropriate market intelligence pertaining to current and future customer needs, and the relative abilities of competitive entities to satisfy these needs; the integration and dissemination of such intelligence across departments; and the coordinated design and execution of the organization's strategic response to market opportunities. This definition brings in two additional dimensions to the concept of market orientation. First, it treats competitor orientation as part of market orientation. Second, it includes strategic response to market opportunities emphasizing the role of top management in the process of market orientation.

\section{Need for Market Orientation}

The needs and expectations of customers continuously evolve over time. Therefore there is a need for a business organization to understand and respond to the evolving customer needs. This helps the business to survive and grow over time. The company has to come out with superior quality products and services to meet the customer needs. Customer needs may change rapidly in a highly technologically turbulent environment. Fast changing technology makes the products obsolete fast. In a highly competitive environment competitors come out with better products and services at competitive prices. A firm has to keep track of the competitive environment and also respond to market place with competitive offerings. As far as a firm is concerned employee satisfaction is also a key variable to be considered. Market orientation is posited to improve employee satisfaction by enhancing the organizational commitment of the employees. By concentrating on market orientation a firm is able to improve its business performance. 


\section{Features of Market Orientation}

According to Shapiro (1988) market orientation encompasses all the aspects of a company. In other words it is the responsibility of all the departments to contribute to being market oriented. It can be considered as a company wide culture.

Information on all the important buying influences should permeate every corporate function. In some industries members of distribution channel may have considerable influence on the buyers' choice (e.g. Dealer). In some other industries nonbuying influences specify the product (for example, architects and doctors). Every department in the company should take cognizance of this fact. It requires regular cross functional meetings. For example, if R\&D people come to know the way a product is used by the customer it will help them to design better products to meet the customer needs. If on the other hand, the marketing people do not part with the information, technologists may miss the opportunities. In addition the top management should meet periodically and evaluate the key points related to important buying influences. Shapiro suggests that "at least once a year, the top functional officers should spend a full day or more to consider what is happening with key buying influences".

Strategic and tactical decisions are made inter-functionally and inter-divisionally. Conflicting interests of functions and divisions should be set aside to focus on the common goal. Divisions and functions make well coordinated decisions and execute them with a sense of commitment. Commitment is more when the one who does the implementation does the planning also. Shapiro (1988) provided the following check list to examine whether a company is market oriented. Are we easy to do business with? Do we keep out promises? Do we meet the standards we set? Are we responsive? And do we work together?

\section{Steps to implement market orientation}

1. The firm should conduct regular marketing research. One of the ways to generate market related information is to conduct in-house marketing research by the marketing research department. Alternatively the firm can also by the market-related information from specialized firms engaged in conducting marketing research. Here the consideration is one of balancing the costs and benefits.

2. The dissemination of market information is also equally important. The company should design and implement a system by which every corporate officer and function has access to market research reports. 
3. Designing and implementing an effective communication system to facilitate vertical and horizontal communication is a pre-requisite for establishing good market orientation. Customer contact employees and sales people are the ones who are closest to the customers. During the normal discharge of their duties they get enormous information about the customer needs. The firm has to effectively utilize this knowledge by transmitting if to the top management as well as to the other functional departments. This type of information is very rich but relatively cheap.

4. The firm should facilitate information gathering by front line employees; for example by establishing toll free customer interaction telephone lines. This facilitates questions and comments from customers and distributors which give enormous insights into market related information.

5. High level executives need to directly interact with the customers and marketing infermediaries to get a richer flavour of market information. This can be done by customer visits, focus groups, trade show visits and dealer and retailer visits.

6. Classifying the customers in terms of their importance and concentrating on important customers. For example, it may be possible to identify certain customers in terms of volume of business and profitability. Concentrating on such customers helps the business to channel the scarce resources of time, effort and money in most effective ways.

7. Establish inter-functional and interdivisional coordination. An open discussion and joint decision making involving different functional areas gets the advantage of both the skills of the specialist and the impartiality of the superior.

8. Devising an incentive plan to reward the pursuit of the organization wide goal.

9. Formation of cross functional teams to represent the inter-functional points of view in achieving the tasks.

\section{Antecedents and Consequences of Market Orientation}

Jaworski and Kohli (1993) have identified several antecedents and consequences of market orientation. The antecedents identified are top management emphasis, risk aversion of top management, inter departmental conflict, inter departmental connectedness, formalization, centralization and departmentalization. A number of hypotheses were advanced related to the antecedents. They are: (a) The greater 
the top management emphasis on a market orientation, the greater the market intelligence generation, intelligence dissemination and responsiveness of the organization. (b) the greater the risk aversion of the top management, the lower the market intelligence generation, intelligence dissemination and responsiveness of the organization. (c) the greater the inter departmental conflict, the lower the market intelligence dissemination and responsiveness of the organization. (d) the greater the inter departmental connectedness, the greater the market intelligence dissemination and responsiveness of the organization. (e) The greater the formalization, the lower the intelligence generation, dissemination, and response design and the greater the response implementation. (f) The greater the centralization, the lower the intelligence generation, dissemination, and response design and the greater the response implementation. (g) The greater the departmentalization, the lower the intelligence generation, dissemination, and response design and the greater the response implementation. (h) The greater the reliance on market based factors for evaluating and rewarding managers, the greater the market intelligence generation, intelligence dissemination and responsiveness of the organization. The above hypotheses were supported by empirical evidences.

As regards the consequences of market orientation, it was hypothesized that the greater the market orientation of an organization, the higher the business performance. The effect of market orientation on business performance is moderated by market turbulence, competitive intensity and technological turbulence. The greater the market turbulence, the stronger the relationship between market orientation and business performance. The greater the competitive intensity, the stronger the relationship between market orientation and business performance. The greater the technological turbulence, the stronger the relationship between market orientation and business performance. The above hypotheses were also empirically supported while using judgmental measures but the relationships were weak while using objective measures like market share.

\section{Measurement Issues}

In the first attempt to measure market orientation Narver and Slater (1990) conceptualizes market orientation as the organizational culture that most effectively and efficiently creates the necessary behaviours for the creation of superior value for the customer. The have operationalised the concepts into three behavioural components of the organization viz, customer orientation, competitor orientation and inter-funtional coordination. The three behavioural components are measured on multi-item scales ( 20 items) and are assumed to be of equal importance and the overall market orientation is measured by averaging the scores on the three components. 
Kohli and Jaworski (1993) operationalized the concept of market orientation into three activities namely market intelligence generation, dissemination and responsiveness. Market intelligence includes information on customers as well as environmental factors. Similarly responsiveness includes response design and implementation. Operationalization resulted in a 32 item scale measuring instrument, the scores of market orientation being calculated by summing the scores of the three components.

Deng and Dart (1994) after a comprehensive literature survey and field study went for a wider conceptualization of the market orientation. They have identified four dimensions of market orientation. They are customer orientation, competitor orientation, inter-functional coordination and profit orientation. Deng and Dart developed a multi item scale with 33 items; 12 items to measure customer orientation, 6 items to measure competitor orientation, 8 items to measure inter-functional coordination and 7 items to measure profit emphasis. The instrument uses a 5 point interval scale. The instrument was subjected to rigorous psychometric testing for validity and reliability.

Brenda and Sheelag developed a better measurement of market orientation in the context of New Zealand. They have incorporated the dimensions from the scales of Narver and Slater, Kohli and Jaworski and Deng and Dart and developed a 44 item questionnaire. They administered the questionnaire to 490 managers from different firms. An exploratory factor analysis resulted in the final selection of 20 items on the dimensions of customer orientation, competitor orientation, inter functional coordination, responsiveness and profit emphasis. The scale has resulted in a more parsimonious measure of market orientation in the context of New Zealand.

\section{Implications of Market Orientation}

Market orientation is supposed to result in better business performance. Thus market orientation predicts business performance. Here the problem is one of defining and selecting an appropriate measure of business performance. A variety of business performance measures are possible like total profits, return on investment, return on equity, share price index, market share etc. There is no agreement among academicians as to which measure of business performance is to be related with market orientation.

Market orientation involves top management commitment. The top management has to design a system by which information about customers and competitors are collected continuously, disseminated within the organization across various departments and develop a company wide culture which facilitates responsiveness to customer needs. 


\section{Development of the Field}

In a path-breaking article in Harvard Business Review, published in 1960, entitled "Marketing Myopia", Theodore Levitt, first propounded the philosophical foundation of the market orientation called "marketing concept". The article pointed out the deficiency in the practices followed by various US corporations due to a narrow definition of their business purposes. The approaches adopted by these corporations were based on production concept, product concept or selling concept. He suggested marketing concept as an alternative. The methodology used was inductive learning from the field.

In a Harvard Business Review article published in the year 1988 Shapiro brought out clearly the meaning of the concept market orientation. He also implicitly brought out the processes involved in making a firm market oriented through the example of a case study. The method used is inductive learning from the field.

Kohli and Jaworski (1990) defined the concept of market orientation and proposed the relationship of market orientation with other organization related variables and proposed the managerial implications through an inductive approach of learning from the field. Narver and Slater (1990) defined and operationalized the concept and developed a scale to measure the concept. Kohli and Jaworski (1993) operationalized the concept and developed a measurement scale. Jaworski and Kohli (1993) in a separate study empirically tested the relationship of market orientation with other organizational variables in the form of antecedents and consequences. Deng and Dart (1994) reconceptualized the concept by widening the scope and developed a more comprehensive multifactor multi-item scale for measurement of the construct.

In an attempt to reconceptualize the construct of market orientation, Cadogan and Diamantopoulos (1995) consolidated and extended the conceptualizations of Narver and Slater and Kohli and Jaworski by positing customer orientation and competitor orientation as the two dimensions of market orientation facilitated by the processes of intelligence generation, intelligence dissemination and responsiveness and superimposed the concept of coordinating mechanism on all the three processes. They further added an internalional dimension to the marketing orientation construct.

Brenda and Sheelag (1998) developed a scale consolidating the dimensions from the previous studies in the context of New Zealand. In an empirical work Andreassen (1994) related the concept of customer orientation with satisfaction, loyalty and reputation in the field of public sector. The study based on Oslo Kommune in Nonway found that satisfaction, loyalty and reputation are the indicators of customer 
orientation. The study found that introducing comparable satisfaction measures may stimulate competition between various service providing bodies which will lead to efficient resource allocation.

In an attempt to study the relationship between market orientation and business performance Pelham (1997) hypothesized that product and customer differentiation has a moderating effect on the relationship. In order to study the moderating effect he classified the firm into four categories operating in different environments namely, differentiated markets, fragmented markets, commodity markets and segmented markets based on Sheth's typology of determinants of industrial competitive structure. Based on statistical (partial correlation) analysis the study concluded that industry environment (product and customer differentiation) has no significant effect on the relationship between market orientation and performance. The study pointed to the importance of treating industry environment as a complex combination of influences and market orientation should be a strong source of sustainable competitive advantage in any industry situation because of the difficulty of influencing corporate culture and the ambiguity about the value of a market orientation culture.

There have been attempts to study the application of market orientation in the context of service industries. Chang and Chen (1998) empirically examined the relationship among market orientation, service quality and profitability by conducting a study among stock brokerage firms in Taiwan. They conducted the study taking a sample of 150 units. The hypothesized relationship was that the service quality has a positive mediating effect on the relationship between market orientation and profitability. Market orientation was hypothesized to have an independent positive effect and positive effects through other mediating variables. The regression analyses confirmed the hypotheses. Market orientation was measured by modifying the Narver and Slater scale to include certain performance anticipation items.

In a study conducted among 289 managers from 67 service organizations Egeren and $O^{\prime}$ Connor (1998) established a positive relationship between market orientation and performance in service firms. The study also identified top management team group dynamics and external environment dynamism as drivers of market orientation by using a structural equation model.

In an attempt to extend the study of market orientation to the context of Australia, Pulendran et.al. (2000) replicated the study by Kohli and Jaworski in Australian industries. They came out with similar findings related to the antecedents and consequences of market orientation. Deng and Dart (1999) in an empirical study examined the extent of market orientation among various types of industries in China and recommended market orientation as a solution to the Chinese enterprises in the current period of transition from a controlled economy to a market economy. 
Table: Development of the Field

\begin{tabular}{|l|l|}
\hline \multicolumn{1}{|c|}{ Stages of Development } & \multicolumn{1}{c|}{ Works } \\
\hline Emergence of Philosophy & Theodore Levitt (1960) \\
\hline $\begin{array}{l}\text { Concept specification and } \\
\text { measurement }\end{array}$ & $\begin{array}{l}\text { Shapiro (1988), Narver and } \\
\text { Slater(1990), Kohli and Jaworski (1990), } \\
\text { Kohli and Jaworski (1993), Deng and } \\
\text { Dart (1994) }\end{array}$ \\
\hline Consolidation and extension & $\begin{array}{l}\text { Cadogan and Diamontopoulos (1995), } \\
\text { Brenda and Sheelag (1998), Uncles (2000) }\end{array}$ \\
\hline Relationship with other concepts & $\begin{array}{l}\text { Jaworski and Kohli (1993), Andreassen } \\
\text { (1994), Pelham (1997) }\end{array}$ \\
\hline $\begin{array}{l}\text { Extension to specific sectors and } \\
\text { geographies }\end{array}$ & $\begin{array}{l}\text { Andreassen (1994), Brenda and Sheelag } \\
\text { (1998), Chang and Chen (1998), Egeren } \\
\text { and O' Connor (1998) }\end{array}$ \\
\hline
\end{tabular}

\section{Conclusion}

Market orientation has been one of the most researched topics in the last decade. It has been found that market orientation leads to better organizational performance. The corner stone of market orientation concept is customer focus. The development of academic literature in market orientation has paralleled the development of practices in the industries. The development of the concept has passed through distinct evolutionary stages as outlined in the paper. Today the concept is of paramount importance to practitioners and academics alike.

\section{References}

1. Andreassen, Wallin T. (1994), "Satisfaction, Loyalty and Reputation as Indicators' of Customer Orientation in the Public Sector", International Journal of Public Sector Management, Vol. 7, No. 2, pp. 16-34.

2. Cadogan, John C. and Diamantopoulos, Adamantios (1995), "Narver and Slater, Kohli and Jaworski and the Market Orientation Construct: Integration and Internalization", Journal of Strategic Marketing, No.3, pp. 41-60. 
3. Chang, Tung-Zong and Chen, Su-Jane (1998), "Market Orientation, Service Quality and Business Profitability: A Conceptual Model and Empirical Evidence", The Journal of Services Marketing, Vol. 12, No. 4, pp. 246-264.

4. Deng, Shengliang and Dart, Jack (1999), "The Market Orientation of Chinese Enterprises during a time of Transition", European Journal of Marketing, Vol. 33 , Issue 5/6, p. 631.

5. Deng, Shengliang and Dart, Jack, (1994), "Measuring Market Orientation: A Multi-factor, Multi-item Approach", Journal of Marketing Management, Vol. 10, No. 8, pp. 725-742.

6. Egeren, Marsha Van and $\mathrm{O}^{\prime}$ Connor, Stephen (1998), "Drivers of Market Orientation and Performance in Service Firms", Journal of Services Marketing, Vol. 12, No. 1, pp. 39-58.

7. Gauzente (1999), "Comparing Market Orientation Scales: A Content Analysis", Marketing Bulletin, Vol. 10, p.76.

8. Gray, Brenda and Matear, Sheelag (1998), "Developing a Better Measure of Market Orientation", European Journal of Marketing, Vol.32, Issue 9/10, p. 884.

9. Jaworski, Bernard J. and Kohli, Aiay K. (1993), "Market Orientation: Antecedents and Consequences", Journal of Marketing, Vol.57, Issue 3, p.53.

10. Kohli, Ajay K. and Jaworski, Bernard J. (1990), "Marker Orientation: The Construct, Research Propositions and Managerial Implications", Journal of Markefing, Vol.54, Issue 2, pp.1-18.

11. Kohli, Ajay K. and Jaworski, Bernard J. (1993), "MARKOR: A Measure of Market Orientation", Journal of Marketing Research, Vol.30, Issue 4, p 467

12. Levitt, Theodore (1960), "Marketing Myopia", Harvard Business Review, Vol. 38 , No.4, pp. 45-56.

13. Narver, J. C. and Slater, S. F. (1990), "The Effect of Market Orientation on Business Profitability", Journal of Marketing, Vol. 58, pp. 20-35.

14. Pelham, Alfred M. (1997), "Market Orientation and performance: The moderating Effects of Product and Customer Differentiation", Journal of Business and Industrial Marketing, Vol. 12, No.5, pp. 276-296.

15. Pulendran, Sue; Speed, Richard and Widing II, Robert E. (2000), "The Antecedents and Consequences of Market Orientation in Australia" ,Australian Journal of Management, Vol. 25, Issue 2, p. 119. 
16. Shapiro, Benson P. (1988), "What the Hell is Market Oriented", Harvard Business Review, November-December 1988, pp.119-125.

17. Uncles, Mark (2000), "Market Orientation", Australian Journal of Management, Vol. 25, Issue 2, ppl 19-128. 